\title{
Meningkatkan Hasil Belajar Pendidikan Kewarganegaraan Materi HAM Melalui Metode Problem Based Learning Bagi Siswa Kelas VII A SMP PGRI Salawati Pada Semester II Tahun Pelajaran 2017/2018
}

\author{
Milka Way \\ SMP PGRI Salawati Kabupaten Sorong \\ Email: waymilka@yahoo.co.id
}

\begin{abstract}
The subject Civilization Education as one of the subject that focus to the establishment of civilization who understand and capable to do their rights and their obligation to be a good, smart, competent and characterized civilization which is mandated by the Five Principals and the Based Constitution 1945. The implementation of learning by using problem based learning is naturally occur in form of students activities work and students experience, find and disscus the problem and try to find the problem solving, not only transfer the knowledge from the teacher to the student. According to the research and the study of the students who passed the learning process, from the pra cycle are consists of 6(six) person (24\%) become 15(Fifteen) students who passed the first cycle (62,5\%) and in the second cycle there are consists of 21(Twenty One) students (87,5\%), so it can be concluded that the using of problem based learning in learn Civilization Education in Human Rights material can increase the result study of the VII ${ }^{\text {th }}$ - A grade students of SMP PGRI Salawati learning year 2017/2018.

Keywords: Problem Based Learning Method, students' result, Pendidikan Kewarganegaraan, HAM, SMP PGRI Salawati
\end{abstract}

\begin{abstract}
Abstrak : Mata Pelajaran Pendidikan Kewarganegaraan merupakan mata pelajaran yang memfokuskan pada pembentukan warga negara yang memahami dan mampu melaksanakan hak-hak dan kewajibannya untuk menjadi warga negara yang baik, cerdas, terampil, dan berkarakter seperti yang diamanatkan oleh Pancasila dan UUD 1945. Pelaksanaan pembelajaran problem based learning berlangsung secara alamiah dalam bentuk kegiatan siswa bekerja dan mengalami, menemukan dan mendiskusikan masalah serta mencari pemecahan masalah, bukan transfer pengetahuan dari guru ke siswa. Berdasarkan hasil penelitian dan pembahasan peserta didik yang tuntas pembelajaran, dari prasiklus sebanyak 6 orang (25\%) mejadi 15 siswa tuntas pada siklus I $(62,5 \%)$ dan pada siklus II sebanyak 21 siswa (87,5\%), sehingga dapat disimpulkan bahwa penggunaan problem based learning dalam pembelajaran Pendidikan Kewarganegaraan (PKn) pada materi HAM dapat meningkatkan hasil belajar bagi siswa kelas VII-A SMP PGRI Salawati tahun pelajaran 2017/2018.
\end{abstract}

Kata kunci: Metode problem based learning, hasil belajar, Pendidikan Kewarganegaraan, HAM, SMP PGRI Salawati

\section{Pendahuluan}

Mata Pelajaran Pendidikan Kewarganegaraan merupakan mata pelajaran yang memfokuskan pada pembentukan warganegara yang memahami dan mampu melaksanakan hakhak dan kewajibannya untuk menjadi warga Negara yang baik, yang cerdas, terampil, dan berkarakter yang diamanatkan oleh Pancasila dan UUD 1945. Pendidikan Kewarganegaraan (Citizenship Education) merupakan mata pelajaran yang memfokuskan pada pembentukan diri yang beragam dari segi agama, sosio-kultural, bahasa, usia, dan suku bangsa. 
Pendidikan Kewarganegaraan adalah sebagai wahana untuk mengembangkan kemampuan, watak dan karakter warga negara yang demokratis dan bertanggung jawab. Ada beberapa hal yang perlu diperhatikan dalam pelajaran Pendidikan Kewarganegaraan (PKn) dalam rangka "nation and character building". Pembelajaran model Problem Based Learning berlangsung secara alamiah dalam bentuk kegiatan siswa bekerja dan mengalami, menemukan dan mendiskusikan masalah serta mencari pemecahan masalah, bukan transfer pengetahuan dari guru ke siswa. Siswa mengerti apa makna belajar, apa manfaatya, dalam status apa mereka, dan bagaimana mencapainya. Mereka sadar bahwa yang mereka pelajari berguna bagi hidupnya nanti. Siswa terbiasa memecahkan masalah, menemukan sesuatu yang bergua bagi dirinya dan bergumul dengan ide-ide. Dalam pembelajaran model Problem Based Learning tugas guru mengatur strategi belajar, membantu menghubungkan pengetahuan lama dengan pengetahuan baru, dan memfasilitasi belajar. Anak harus tahu makna belajar dan menggunakan pengetahuan dan keterampilan yang diperolehnya untuk memecahkan masalah dalam kehidupannya.

Banyak faktor yang menyebabkan hasil belajar Pendidikan Kewarganegaraan (PKn) siswa kelas VII-A rendah yaitu faktor internal dan eksternal dari siswa. Faktor internal antara lain: motivasi belajar, intelegensi, kebiasaan dan rasa percaya diri. Sedangkan faktor eksternal adalah faktor yang terdapat di luar siswa, seperti; guru sebagai pembina kegiatan belajar, startegi pembelajaran, sarana dan prasarana, kurikulum dan lingkungan.

Berdasarkan uraian di atas maka Penelitian Tindakan Kelas (PTK) ini, dirancang untuk mengkaji Penerapan Pembelajaran Model Problem Based Learning dalam meningkatkan kemampuan memecahkan masalah HAM dalam mata pelajaran Pendidikan Kewarganegaraan (PKn) siswa kelas VII-A SMP PGRI Salawati tahun pelajaran 2017/2018 semester II.

\section{Metode Penelitian}

\subsection{Desain Penelitian}

Penelitian ini merupakan penelitian tindakan kelas (classroom action research) yang dilakukan oleh peneliti dengan mencoba menerapkan variasi model pembelajaran yang baru yaitu pada pembelajaran menggunakan model pembelajaran Problem Based Learning. Penelitian tindakan kelas ini terdiri atas rangkaian empat kegiatan yang dilakukan dalam siklus berulang. Empat kegiatan utama yang ada pada setiap siklus, yaitu : (1) Perencanaan (planning), yaitu persiapan yang untuk pelaksanaan PTK, (2) Tindakan (acting), yaitu deskripsi tindakan yang akan dilakukan, skenario tindakan, perbaikan dan prosedur tindakan yang diterapkan, (3) Observasi (observing), yaitu kegiatan mengamati dampak atas tindakan yang dilakukan, dan (4) Refleksi (reflecting), yaitu kegiatan evaluasi tentang perubahan yang terjadi atau hasil yang diperoleh atas data yang terhimpun sebagai bentuk dampak tindakan yang telah dirancang.

Adapun siklusnya dapat digambarkan sebagai berikut : 


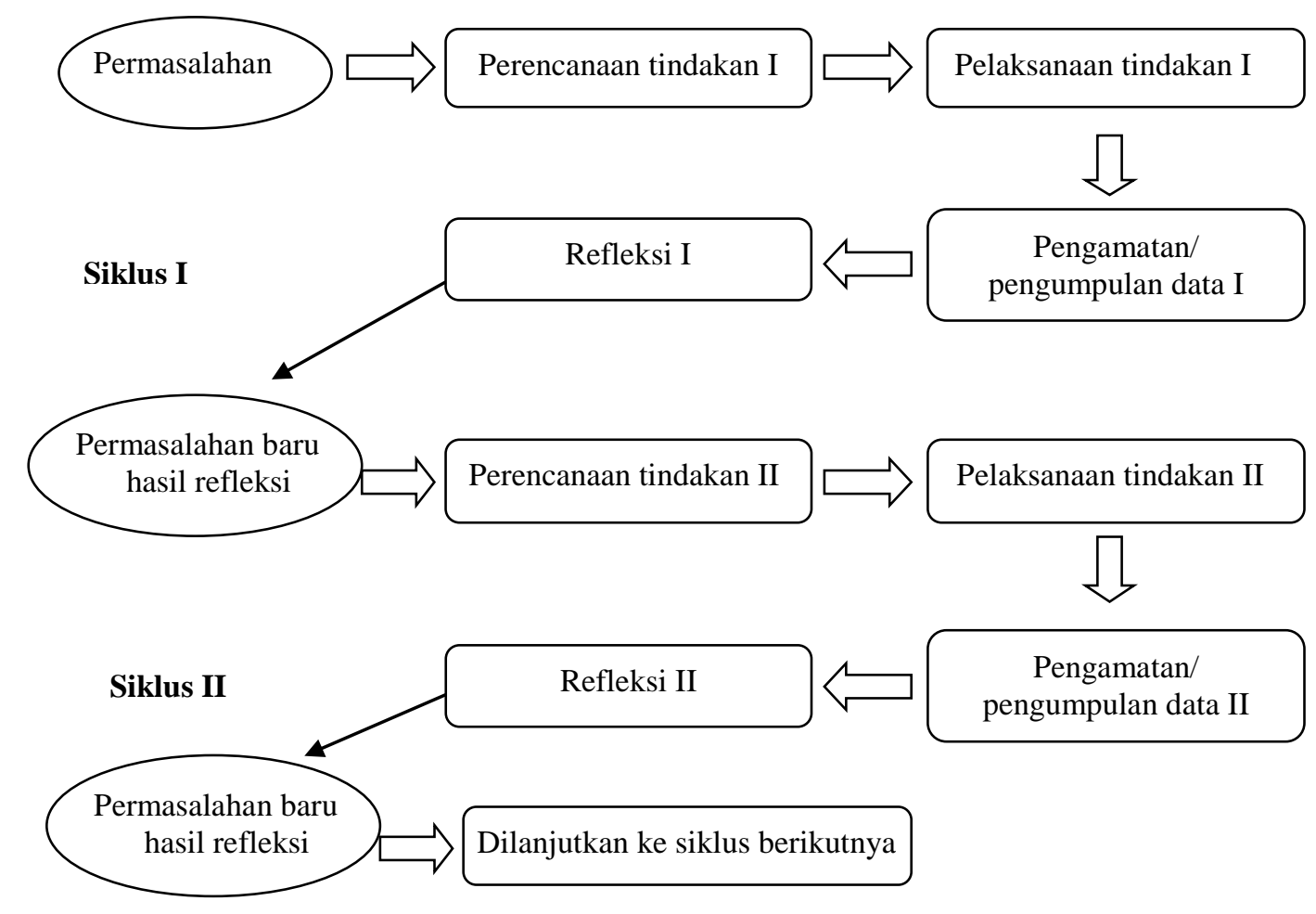

Gambar 1. Siklus Penelitian Tindakan Kelas (Suharsimi Arikunto, 2013: 74)

\subsection{Waktu dan Tempat Penelitian}

Penelitian dilaksanakan di SMP PGRI Salawati Kabupaten Sorong yang beralamat di Jalan Nusantara Majaran, Distrik Salawati Kabupaten Sorong.

\subsection{Subjek Penelitian}

Penelitian ini diterapkan pada siswa kelas VIIA SMP PGRI Salawati dengan jumlah siswa adalah 24 orang yang terdiri dari 11 orang laki-laki dan 13 orang. Kelas VII A SMP PGRI Salawati Kabupaten Sorong dipilih karena model pembelajaran Problem Based Learning untuk pembelajaran pada PKn belum pernah diterapkan di kelas tersebut. Peneliti memilih siswa kelas VII A karena mereka belum mencapai KKM untuk mata pelajaran Pendidikan Kewargangaraan (PKn).

\subsection{Teknik Pengumpulan Data}

Pada penelitian ini, data diperoleh dengan cara: (1) Observasi (Observation), yaitu mengamati secara langsung kegiatan pembelajaran di kelas dengan menggunakan model pembelajaran Problem Based Learning, (2) Wawancara, dengan cara mengajukan sejumlah pertanyaan secara verbal kepada siswa yang dianggap dapat memberikan informasi atau penjelasan mengenai hal-hal yang dianggap perlu, (3) Tes, untuk mengumpulkan data tentang hasil belajar siswa dalam upaya peningkatan prestasi siswa, dan (4) Dokumentasi, untuk 
mendapatkan data mengenai kegiatan yang terjadi selama pembelajaran berlangsung yang berupa foto atau gambar.

\subsection{Teknik Analisis Data}

Analisis data yang digunakan dalam penelitian ini adalah analisis deskriptif kuantitatif. Adapun yang dianalisis adalah:

a. Partisipasi aktif siswa

Kriteria menghitung persentase partisipasi siswa berdasarkan lembar observasi adalah sebagai berikut :

Tabel 1. Kriteria Aktivitas Individu

\begin{tabular}{cc}
\hline Persentase & Kriteria aktivitas siswa \\
\hline $81 \%-100 \%$ & Sangat tinggi \\
$61 \%-80 \%$ & Tinggi \\
$41 \%-60 \%$ & Sedang \\
$21 \%-40 \%$ & Rendah \\
$0 \%-20 \%$ & Sangat rendah \\
\hline
\end{tabular}

(Riduwan, 2009: 15)

Cara menghitung persentase aktivitas siswa berdasarkan lembar observasi untuk tiap pertemuan adalah sebagai berikut :

$$
\text { Persentase }=\frac{\begin{array}{c}
\text { Skor Perolehan } \\
\text { (Jumlah Siswa Yang Berpartisipasi })
\end{array}}{\text { Skor Maksimal }} \times 100 \%
$$

(Martinus, 2013: 49)

b. Prestasi Belajar Siswa

Untuk mengetahui peningkatan prestasi belajar siswa, peneliti menggunakan Kriteria Ketuntasan Minimal (KKM) pada mata pelajaran PKn, yaitu 75.

\section{Hasil dan Pembahasan}

\subsection{Hasil Penelitian}

Hasil ulangan harian siswa kelas VII-A SMP PGRI Salawati pada materi HAM hasilnya belum memuaskan. Hasil ulangan harian menunjukkan bahwa dari 24 siswa hanya 6 orang saja yang mendapatkan nilai 75-80, berarti 18 sisanya mendapat nilai berkisar antara 60-74. Kondisi ini belum sesuai dengan yang diharapkan sekolah.

Tabel 2. Nilai Ulangan Kondisi Awal

\begin{tabular}{cccc}
\hline No & & Uraian & Ulangan Harian \\
\hline 1 & Nilai Terendah & 65 \\
2 & Nilai Tertinggi & 80 \\
\hline
\end{tabular}




\begin{tabular}{llc}
\hline 3 & Nilai Rerata & 72.5 \\
4 & Rentang Nilai & 15 \\
5 & Ketuntasan & 6 \\
\hline
\end{tabular}

Tabel 2 di atas menunjukkan hasil yang belum memuaskan. Pada kondisi awal ini guru belum menggunakan pembelajaran berbasis masalah (problem based learning) sebagai metode pembelajaran. Kondisi di atas digambarkan dalam grafik 1 berikut.

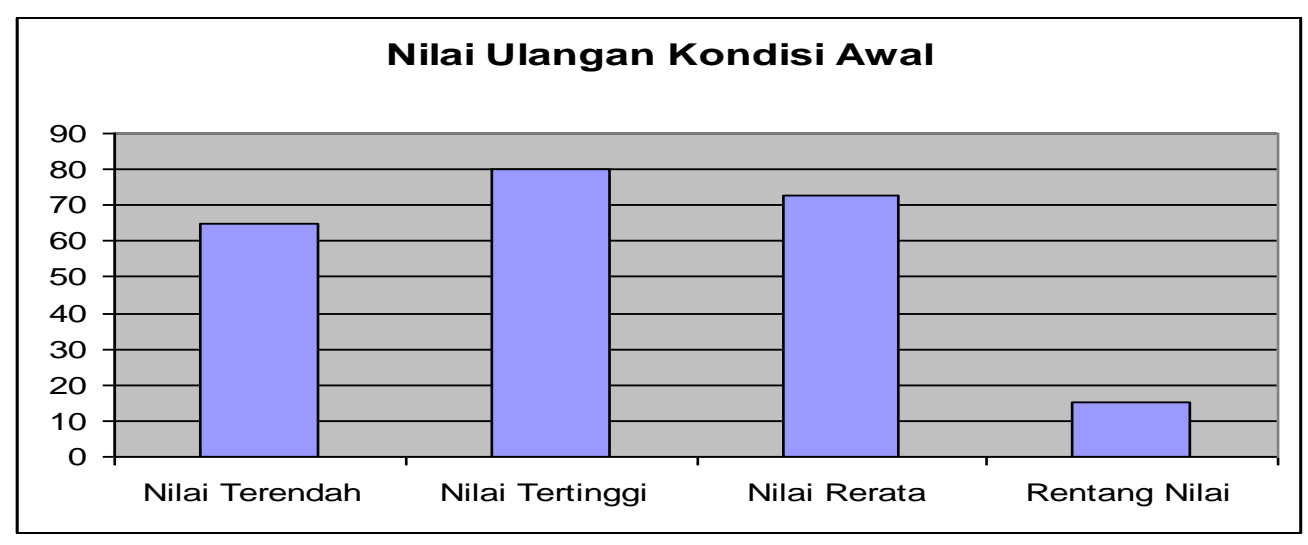

Grafik 1. Nilai Ulangan Kondisi Awal

\subsubsection{Hasil Siklus I}

Kegiatan pembelajaran Pendidikan Kewarganegaraan (PKn) ini menggunakan pendekatan problem based learning pada setiap siklusnya. Dalam pembelajaran ini siswa dibagi dalam kelompok besar. Penerapan pendekatan problem based learning pada setiap kegiatan pembelajaran ini terlihat dari 3 unsur yang menjadi ciri penerapan problem based learning dalam kegiatan pembelajaran tersebut, yaitu selalu dikaitkan dengan masalah secara langsung. Selalu ada kegiatan berupa pengamatan dan penjelasan dan ada laporan untuk dikomunikasikan baik secara lisan, dan tulisan. Kegiatan pembelajaran berlangsung dengan siswa memperhatikan diberikan sebuah kasus untuk dipecahkan.

Pada siklus I, setelah diadakan penggunaan problem based learning, siswa mulai termotivasi untuk mengikuti pelajaran. Siswa tidak lagi merasa bosan meskipun tidak secara keseluruhan. Hasil pelaksanaan ulangan harian pada siklus I dengan problem based learning pada materi HAM dapat lihat pada tabel 3 berikut ini.

Tabel 3. Hasil Ulangan Siklus I

\begin{tabular}{clcc}
\hline No & & Uraian & UH I \\
\hline 1 & Nilai Terendah & 70 \\
2 & Nilai Tertinggi & 85 \\
3 & Nilai Rerata & 77.5 \\
4 & Nilai Rentang & 15 \\
\hline
\end{tabular}


Data di atas dapat dibuat grafik sebagai berikut.

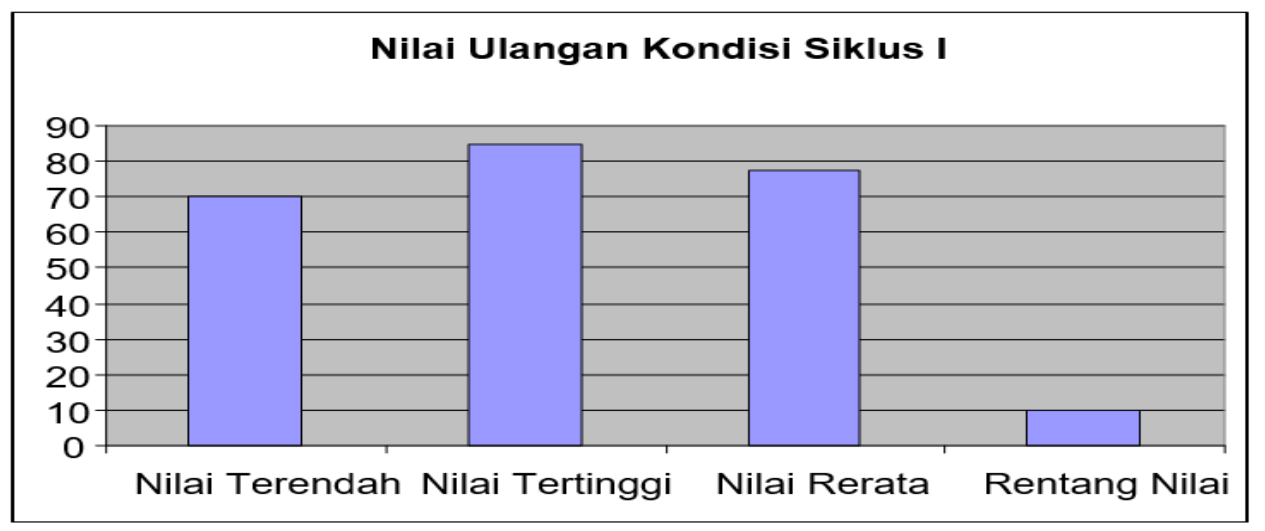

Grafik 2. Hasil Ulangan Siklus I

\subsubsection{Hasil Siklus II}

Hasil pelaksanaan kegiatan pembelajaran pada siklus II dengan problem based learning pada konsep materi HAM ini dapat dilihat pada tabel 4 berikut ini.

Tabel 4. Hasil Ulangan Siklus II

\begin{tabular}{clcc}
\hline No & & Uraian & UH I \\
\hline 1 & Nilai Terendah & 74 \\
2 & Nilai Tertinggi & 90 \\
3 & Nilai Rerata & 82.5 \\
4 & Nilai Rentang & 16 \\
5 & Ketuntasan & 21 \\
\hline
\end{tabular}

Data di atas dapat dibuat grafik sebagai berikut:

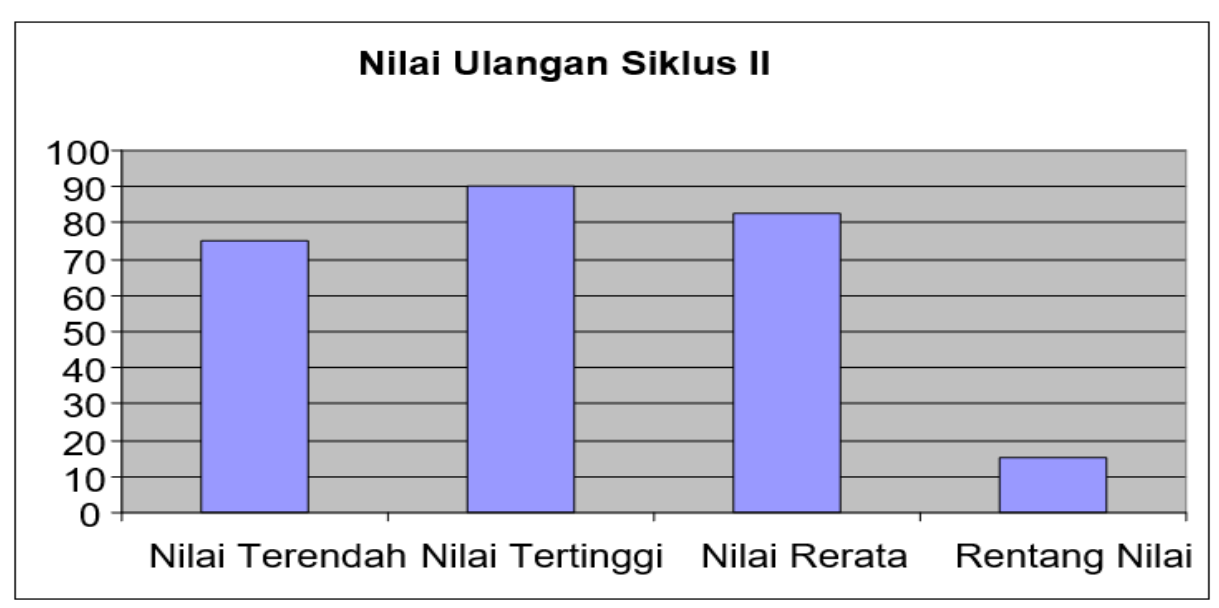

Grafik 2. Hasil Ulangan Siklus II 


\subsection{Pembahasan}

Perhitungan hasil belajar pada siklus I menunjukkan peningkatan dari kondisi awal. Beberapa faktor penyebabnya antara lain: kurangnya persiapan siswa sebelum mengikuti proses pembelajaran seperti siswa yang masih belum terlatih dan terbiasa melakukan kegiatan pembelajaran menggunakan bagan, serta masih ada yang tidak suka dengan mata pelajaran Pendidikan Kewarganegaraan (PKn) dan aktivitas siswa selama proses pembelajaran berlangsung rendah.

Hasil belajar siswa pada siklus II, menunjukkan peningkatan. Hasil ini menunjukkan adanya peningkatan jumlah siswa yang tuntas belajar. Peningkatan hasil belajar yang terjadi pada siklus II tidak terlepas dari tindakan-tindakan yang diambil dari refleksi siklus sebelumnya, yaitu dengan memberikan batas waktu agar siswa disiplin dan benar-benar memanfaatkan waktu hanya untuk kegiatan yang mendukung proses pembelajaran. Pada siklus II ini siswa juga sudah mulai merasa terbiasa melakukan kegiatan pembelajaran.

Hasil belajar ini dipengaruhi karena adanya ketertarikan siswa selama pembelajaran melalui media bagan. Ketertarikan siswa pada pembelajaran dapat dilihat pada siswa tertarik dengan pembelajaran yang dilakukan dengan menggunakan melalui media bagan. Ketertarikan siswa pada pembelajaran yang dilakukan menyebabkan perhatian, motivasi dan minat belajar serta aktivitas siswa terbentuk tumbuh. Perhatian, motivasi, minat, dan aktivitas atau keterlibatan siswa dalam proses pembelajaran merupakan beberapa faktor pendukung keberhasilan hasil belajar. Perhatian siswa terhadap pelajaran sangat penting untuk menjamin hasil belajar yang baik. Materi pelajaran yang tidak mendapat perhatian dari siswa karena penyajiannya tidak menarik akan menimbulkan kebosanan pada diri siswa yang akhirnya mempengaruhi penurunan hasil belajar.

Berdasar pada uraian di atas menunjukkan bahwa penggunaan model pembelajaran problem based learning dapat meningkatkan pemahaman siswa tentag sistem pemerintahan.

\section{Simpulan dan Saran}

\subsection{Kesimpulan}

Berdasarkan hasil penelitian dan pembahasan dapat disimpulkan bahwa penggunaan model pembelajaran problem based learning dalam pembelajaran Pendidikan Kewarganegaraan (PKn) pada materi HAM dapat meningkatkan hasil belajar bagi siswa kelas VII A SMP PGRI Salawati tahun pelajaran 2017/2018. Hal itu dapat dilihat dari kenaikan peserta didik yang tuntas pembelajaran, dari prasiklus sebanyak 6 orang (25\%) mejadi 15 siswa tuntas pada siklus I $(62,5 \%)$ dan pada siklus II sebanyak 21 siswa $(87,5 \%)$ yang tuntas belajarnya. 
Peningkatan hasil belajar siswa dalam materi HAM dipengaruhi karena adanya ketertarikan siswa selama pembelajaran dengan menggunakan problem based learning. Oleh karena itu perlu dilakukan penerapan lebih lanjut untuk membantu proses pembelajaran.

\subsection{Saran}

Ada beberapa saran yang dapat penulis ajukan berdasarkan hasil penelitian ini, antara lain:

a. Bagi Dinas Pendidikan untuk mengadakan pelatihan penerapan pembelajaran dengan menggunakan problem based learning.

b. Bagi sekolah perlu diadakan persiapan yang matang serta pengelolaan waktu yang seefektif mungkin dan efisien sehingga dapat mengoptimalkan pembelajaran dengan menggunakan problem based learning.

c. Bagi guru perlu adanya penelitian pada materi yang lain melalaui pembelajaran menggunakan problem based learning untuk lebih mengetahui pengaruhnya terhadap hasil belajar dan kualitas belajar siswa.

\section{Daftar Pustaka}

Abdullah, H. Rozali, dan Syamsir, 2002. Perkembangan Hak Asasi Manusia dan Keberadaan Peradilan Hak Asasi Manusia di Indonesia. Jakarta: Ghalia Indonesia.

Anonim, 2006. Peraturan Menteri Pendidikan Nasional No. 22 Tahun 2006 Tentang Standar Isi, Jakarta.

Aqib, Zainal. 2006. Penelitian Tindakan Kelas untuk Guru. Bandung: Yrama Widya.

Arikunto Suharsimi, dkk, 2006. Penelitian Tindakan Kelas. Jakarta: Bina Aksara.

Arikunto Suharsimi. 2006. Dasar-dasar Evaluasi Pendidikan (Edisi Revisi). Jakarta: Rineka Cipta.

Darsono, M, dkk. 2000. Belajar dan Pembelajaran. Semarang: IKIP Semarang Press

Depdiknas, 2006, Standar Kompetensi Kurikulum Pendidikan Kewarganegaraan Tahun 2006. Jakarta: Depdiknas.

Dimyati dan Mudjiono. 2002. Belajar dan Pembelajaran. Jakarta: Rineka Cipta. 